\title{
The research of the Flip classroom teaching mode in college English teaching
}

\author{
Ming Yang \\ Hanjiang Normal University, Shiyan, Hubei Province, China
}

Keywords: Flip classroom, Teaching mode, College English, English teaching.

\begin{abstract}
Flip classroom refers to the internalization of knowledge and knowledge of reverse arrangement, change the roles between teachers and students in the traditional teaching and the use of classroom time to plan, implement the innovation of traditional teaching mode. In turn classroom, information technology and active learning for learners to construct individualized collaborative learning environment, helps to form the new culture of learning. By flipping around class origin, concept and characteristics of analysis, on the basis of case studies of foreign teaching practice, build a flip classroom teaching model, in order to improve the quality of English teaching.
\end{abstract}

\section{Introduction}

With the rapid development of science and technology and the advancement of reform and opening up career impact on all aspects of China has brought new. The rise of the "flip" class has produced significant influence in the education circle. , in the face of the new education idea, middle school English classroom teaching requires complete comprehensive reform from theory to practice; Turn as an important foundation of teaching, classroom teaching design success will flip the classroom teaching effect and high efficiency to provide a strong foundation.

\section{The concept of Flip classroom}

Flip the classroom is to turn the traditional classroom. Traditional ways of teaching basic are all teachers to teach new knowledge in the classroom, students after class complete knowledge internalization, the review and assignments. They turn over the opposite class; the teacher can be in before the beginning of recorded teaching video online for students to watch, they no longer interminably lectures in class, but when the students need to provide the necessary guidance and help. Students really become the center of the learning process [1]. Extracurricular they can independent arrangement study time, actively explore the problem; they can ask the teacher in class or cooperate with classmates solve encountered in the process of learning or finish my homework.

"Flip" classroom is different from the past traditional teaching, has its unique connotation and the characteristic, first of all know its connotation and characteristics, to further carry out classroom teaching has important guiding significance [1]. The traditional teaching, pay attention to teachers' classroom teaching, classroom teachers as the center; Students need to be in accordance with the class teacher to not finish the assignment, in order to achieve consolidated master knowledge, finally achieve the goal of internalization. In fact, students knowledge internalization is mainly rely on class independently, if students self-control is poor, or did not fully understand the class teacher speak knowledge, it will be difficult to knowledge internalization into their own knowledge. "Flip" class is completely subverts the traditional teaching mode, the so-called "flip", is not only the teacher role transformation, not only is the student role transformation, but also the whole ranging from teaching design, the teacher prepares a lesson, class organization, class activities, teaching evaluation, teaching reflection of the whole teaching process "flip" thoroughly [1]. 


\section{The influence factors of turn college English classroom teaching design}

Classroom "flip" concept into the university teaching, combining the characteristics of English subject, has overall impact on the English classroom teaching, and are turning to the traditional English classroom mode, explore the change of preparation for teaching and teaching design has a vital role.

Turn the college English classroom. College English to flip the whole class teaching process made a radical turn changed the traditional teaching with the teacher as the center; students become the center of the classroom and learning. The teaching process is basically like this:

Learning content is introduced into $\rightarrow$ Video program (students) independently before class $\rightarrow$ Problem solving (mainly to students in class discussion and activities involved in, the teachers guide is complementary) $\rightarrow$ Learning feedback (shown as Fig. 1).

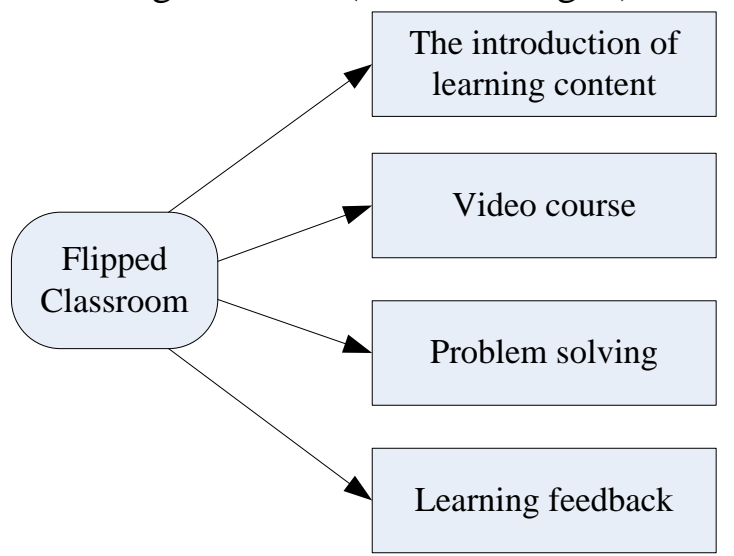

Fig. 1 The teaching process of flip classroom

Through the above diagram, for the role of teacher in the whole teaching process change will be clear at a glance. No matter adopt what kind of teaching mode, education idea, the final purpose is to improve the quality of English teaching to students and students for learning language knowledge internalization, free to use the language communication teaching goal in the end.

Flip the classroom knowledge internalization in learning English. Turn in college English class, the teaching process of "generally consists of three links: problem guide link, watch the video link and problem solving link". Turn accordingly, can be found in college English classroom teaching process, students completed the knowledge internalization [2]. In guide link, to learn the language knowledge had first internalized and thinking; watch video in class learning, a second is deep internalization; in the classroom discussion activities link, finished third internalization of language knowledge.

Through the above research, found the key to knowledge internalization on students' participation, turn the students in the class has a higher participation and internalization is higher, the higher the efficiency of learning. The roles of teachers and students have very big change. Teachers will put more energy on boot, video production and classroom discussion activities arrangement design, in order to make students better use of classroom teaching time and more efficient under the classroom self-study time, achieve the desired objectives [2]. As the organizer of the whole teaching process designers, flip the completion of the entire process effective classroom teaching tasks, teaching goal mainly depends on the arrangement of the whole teaching design and the design of science degree and the validity and practicality.

\section{The implementation conditions of University English Flip classroom teaching}

First, the technical support, due to the new teaching mode in advance will need teachers to teach the course for video, and then the students will the download is complete, as required for learning and thinking. This presents a challenge to the teacher, if is video recording is not good, students have no interest in learning, to reach the teaching goal [2]. At the same time, the students also need to have a 
certain technical support, students need to staff a terminal device, and however, for the situation of the students in our school, it's a bit difficult to achieve this.

Second, students need to have enough self-study time. Due to flip the teaching mode of classroom teacher asked the students to record video download and for learning and thinking, so students need a lot of free time to finish before learning to think, so, I suggest should leave time to night lessons for students learning freedom.

Third, the learners have strong ability of autonomous learning. Flip the classroom teaching mode, after class, students need to arrange your time take the initiative to watch the teaching video, after watching the video initiative to ask questions, solve problems, and communicate with classmates and teachers [3]. These requirements for students' autonomous learning ability are very high. The students in our school is not very good at independent exploration, the majority of students are accustomed to passive to accept knowledge, poor ability of autonomic learning. Once a lot of students leave teacher's supervision and guidance, you don't want to learn or not. This requires teachers to guide and supervise, students must also rely on the teachers to determine learning content, access to learning strategies, provide feedback, and we cannot solve the learning difficulties, especially need to teacher's guidance and help.

\section{The Flip the classroom teaching model design of University English teaching}

In under the long influence of the traditional teaching mode, teachers and students about their role in the whole teaching process and the role of has solidified stereotypes; In the face of new teaching ideas, only the first respective roles to teachers and students have a clear understanding, English teachers should grasp the teaching design of the whole process of teaching, to make a perfect blueprint, can urge the students to have more clear understanding of the role of, make the teaching and learning bring out the best in each other, the whole teaching process more smoothly, more efficient, and to achieve the expected teaching effect [3].

Traditional teaching process typically includes knowledge transfer and within the knowledge of the two phases. Imparting knowledge is taught by teachers in the classroom to complete, within the knowledge of the needs of students in after-school through the job, operation or practice to complete [5]. On the flipped classroom, this form has been subverted by imparting knowledge of information technology supporting the completion of the class, knowledge is internalized by assisting in the classroom to help teachers and students accomplished, thus forming a flipped classroom [4]. With the reversal of the teaching process, classroom learning process in all aspects also will be changed (shown as fig. 2).

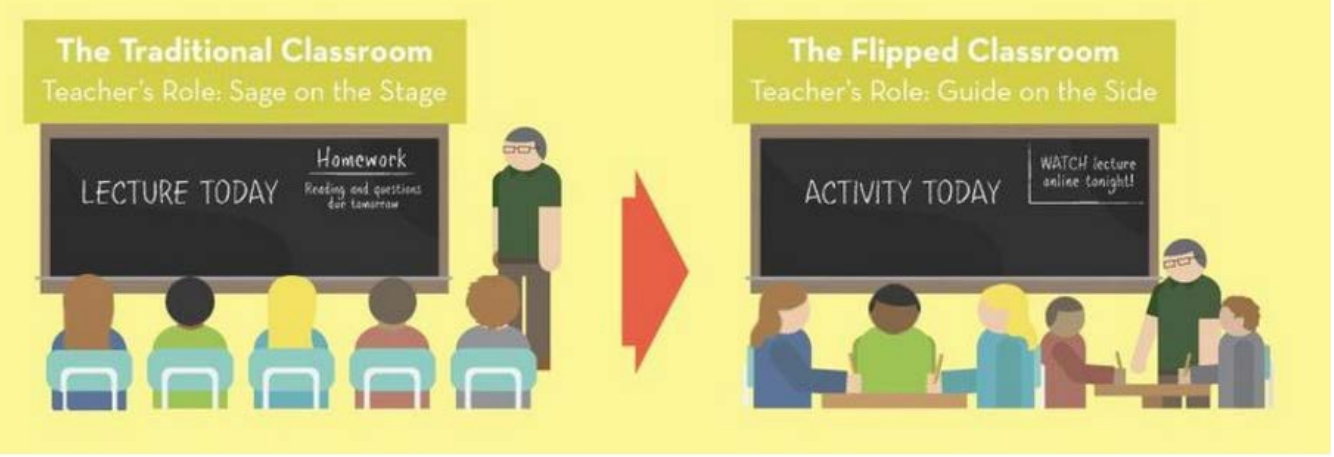

Fig. 2 Differences between Flip class and traditional classroom

Model design before class. 1) the teacher teaching courseware and teaching video using flip classroom teaching model, students can independently control after class time, so the teachers should more pay attention to when making the teaching video design in listening, speaking, and provide students with more opportunities to practice listening and speaking English [4]. In addition, in order to guarantee the teaching effect, in each teaching link teachers should formulate specific teaching goal, design targeted practice or tests, and urge students to complete the task as required.

2) Request students to etch the video and specific exercises, watching video teaching process, students can independently control the learning process, at any time suspend or playback. In the 
process of learning or practice if you have not understand of place, students should take the initiative to rely on their own ability to explore, to solve the problem. If they can't solve, can be recorded, the question to ask teachers or classmates in class [3]. Because some students because of the traditional class embarrassed or shy don't want to speak English, but after using flip classroom teaching mode, because it is at home to watch the teaching video, so students can rest assured bold to practice oral English, no one will laugh at or criticize them.

3) The teachers and students discuss solving, teachers and students can communicate through communication platform (QQ group) encountered in the process of learning and learning problems. The traditional classroom, students and teachers exchange opportunities, limited to "teacher questions, students answer" [5]. And in turn the classroom communication platform, because the time is more abundant, teachers and students will have more communication opportunities. And because don't have to and the teacher face to face, a lot of students in communicating with teachers not overly anxious and nervous, and more willing to express their own ideas. In addition, on the communication platform, teachers can ask students to talk in English, to help students improve English application ability.

Classroom teaching design. 1) The teacher difficult and disposing the learning task. By talking with students on the communication platform, teachers can understand students before the class what problems encountered in the process of learning. Classroom teachers can use a little time to explain some common problems, not only highly targeted, and high efficiency, for teacher's explanation is what students need to knowledge [5]. After the interpretation of the teachers will homework or learning tasks, such as requiring students' English words dictation, English conversation practice, such as a topic to discuss in English.

2) the students group collaboration is often used in English class activities organization form. Flip the classroom, the advantage of group collaboration, will get better. As long as the students are willing to, and learning task can be done on grouping. Dictation words, for example, can a classmate read words, other students write, and then in another classmate to read [5]. So every students in a short time can get plenty of opportunities to practice and test study achievement, learning efficiency greatly. Another advantage of group collaboration between team members can help each other, mutual supervision, and common progress. Bad grades of the students in general are reluctant to seek help the teacher, more willing to ask classmates. The result good students in the process of helping others to disabuse themselves will also get further consolidate knowledge.

3) Teachers walked down the platform to communicate with students and guidance. Walked down the platform in the process of communication with students, teachers should try to establish similar to a friend's relationship with students [6]. In the beginning, there will still be afraid of the majority of students to teachers and even alert psychological, but when to teachers for their respect and support, they will open the gate, real express their ideas and the confusion in the process of learning. In the process of communication with students, teachers should carefully observe the characteristics of each student to understand their special features and the insufficiency, targeted guidance, try to realize the potential of each student and talents. In addition, teachers should encourage students to use English to talk with you, and to cultivate their English listening and speaking skills.

4) To summarize the learning process. Both teachers and students to summarize the learning process is very important, because this is not only to evaluate before learning, also for the future study on removing obstacles. Each study group in order to save time can be summed up in the group while learning task, 10 minutes before class is the summary results report to teacher [6]. According to the results of the report and what they finally summarized to observe and understand the situation.

Teaching pattern design after class. 1) the students to review and consolidate the knowledge of practice after class, and the guidance of teachers, students and help, if some students still have some doubts about some knowledge, they can watch the teaching video again or through communication platform to communicate with teachers, with to solve the problem. Before take a test or examination, students can also watch the video again for review [6].

2) the teacher summed up the teaching process and improve the teaching content after class teachers should be completed according to the learning objectives, found the problem from the 
student work and discussion, a summary of the whole teaching process and teaching content in a timely manner, the reflection in the teaching process, and avoid the same problem in the future [2]. The other teachers also should have taken the time to communicate with students, understand students' learning needs, and to encourage students teaching Suggestions and opinions.

\section{Summary}

Using flipped classroom teaching mode in English courses allow students to relatively complex step more skills repeatedly watching video, to understand the effect of memory. To avoid the traditional classroom teachers operating demonstrate again the blind imitation of the students when the students hands-on due to the limited memory capacity and the emergence of let. Students With a flipped classroom model, before class to master basic skills rate has reached a certain percentage, and links to the students left the classroom enough time for students to self-inquiry and cooperative learning. So this part of the students' learning ability can help raise get deeper and develop a wide range, but also promote the formation of College English teaching higher-order capabilities.

\section{References}

[1] Zh.Y.Guo, Y.J. Zhang, Perspective of "flipped classroom", Primary and Secondary Schools IT education, 2012, pp. 21-27.

[2] AN.. Yang and T. Chen, Flip the classroom teaching mode in colleges and universities in China application feasibility analysis, Primary and Secondary School Information Technology Education, 2013, vol. 7, pp. 65-69.

[3] K.Ke, Theoretical basis to reform the traditional teaching, Educational research, 1997, pp. 33-36.

[4] W.S. Y, Analyses of the quality problem of the multimedia classroom teaching in colleges and universities, The theory of observation, 2010, pp.8-12.

[5] X.L. Ma and G.Q. Zhao, Common course at the university to flip the empirical study of classroom teaching, Distance education journal, 2013, vol. 1, pp.91-95.

[6] J.L. Zhang and T.G. Wang, Classroom teaching model research, Distance education journal, 2012, vol.4, pp.43-48. 